\title{
Hydrodynamics of Packing Beds Made of Differently Structured Material for Thermal Utilization and Mass-Exchanged Processes in Columns of Environment Protection
}

\author{
Alexandr Pushnov, Michael Berengarten, Alexey Sevryukov \\ Moscow State University of Mechanical Engineering (Mami), Bolshaya Semenovskaya st. 38, Moscow, 107023, Russia
}

\begin{abstract}
The submitted concept is a new perspective design of regular packing of PFF type (fluctuating packing "flag") made of thin, elastic, wetted cloth materials. One end of packing bed elements is fixed on rigid framework, and another enables to make free vibrational motions under the influence of incoming gas stream. Using of the proposed packing bed of PFF type allows, to develop a contact surface up to $400 \mathrm{~m}^{2} / \mathrm{m}^{3}$, having increased thereby the efficiency of heat-and-mass transfer process performance in environment protection units.
\end{abstract}

Keywords: environment protection; regular packing bed; heat-and-mass transfer processes; hydrodynamics.

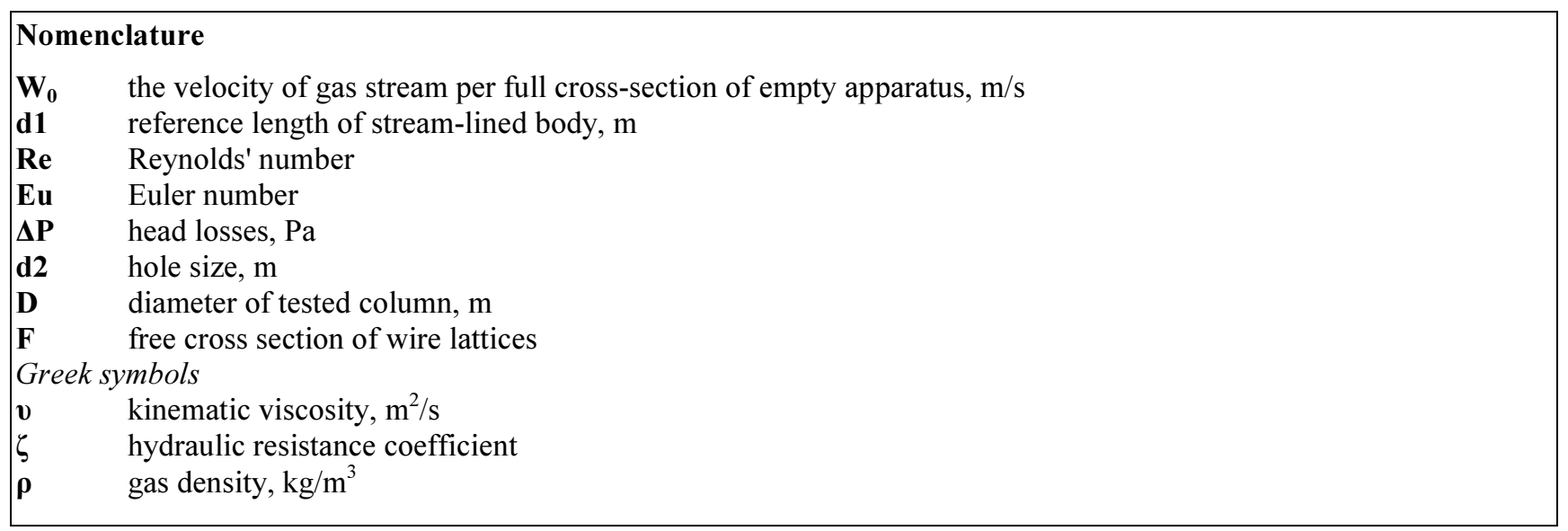

\section{Introduction}

Sulfur and nitrogen oxides can be related to the main harmful gaseous emissions, for example, at the coal-fired power stations (see Table 1). According to data [1, 2], the quantity of sulfur dioxide emissions in the atmosphere of Earth in 2008 was more than 4 million tons. It accounts for about $23 \%$ of total emissions from all industrial sources in Russia.

Unlike the European Community countries, where the total quantity of coal fuel from the fuel stock ranges from 40 to $50 \%$, in Russia it amounts to $30 \%$ and as to natural gas $-60 \%$. For this reason the experience of implementing the wet-type purification (filtration) technologies of sulfur oxide combustion gases in the power industry of Russia is now limited. However, research works in this area are carried out quite actively [1, 3-12].

The most regular packing of falling film type used at present in the power industry are made of the structured corrugated plates vertically installed in the unit of equipment [4, 7, 11-15]. The metal or plastic is usually used as a material for manufacturing these corrugated plates. It is possible, to illustrate the structured packing bed as an example of a similar packing of Montz Pak B1-250M type, which allows to develop geometrical surface of contact up to the size $\mathrm{a}=250 \mathrm{~m}^{2} / \mathrm{m}^{3}$. The specified packing bed is arranged inside the column in tiers, the height of which is $0.2 \mathrm{~m}$ [13-15]. For this purpose the

Corresponding author: Alexey Sevryukov. E-mail address: 1404alex@gmail.com

http://dx.doi.org/10.3846/enviro.2014.047

(C) 2014 The Authors. Published by VGTU Press. This is an open-access article distributed under the terms of the Creative Commons Attribution License, which permits unrestricted use, distribution, and reproduction in any medium, provided the original author and source are credited. 
adjoining tiers are performed with 90-degree turn relative to each other, that provides permanent disruption of liquid film so intensifying to some extent the heat-and-mass transfer by using "end" effects [16].

Table 1. Atmospheric pollutant emissions from stationary sources in the Northwestern Federal District of Russia [2]

\begin{tabular}{|l|l|}
\hline Emissions & Thousands of tons per year \\
\hline Sulphur dioxide & 554,2 \\
\hline Carbon oxide & 705,7 \\
\hline Nitrogen oxides & 168,5 \\
\hline Solid particles & 273,9 \\
\hline Total & 2243,9 \\
\hline
\end{tabular}

If the regular corrugated packing bed is used, the main tool enabling to provide rather high specific surface is a manipulating corrugated plates in height. The less the height of corrugated plate is, the greater is the figure of the developed geometrical specific surface. The tilt angle of corrugated packing beds to the horizontal of packing beds in question usually makes $45-60^{\circ}$ [8-9]. The plate thickness is from 0,1 to $0,5 \mathrm{~mm}$ depending on the used material. The specific surface, which for instance differently manufactured packing FLEXIPAC HC of KOCH-GLITSCH firm has is from $225 \mathrm{~m}^{2} / \mathrm{m}^{3}$ (type $2 \mathrm{Y}$ ) up to $725 \mathrm{~m}^{2} / \mathrm{m}^{3}$ (type 700Y) [14]. At the same time it is noted, that when being used [10] even at the smaller size of the specific surface equal to $500 \mathrm{~m}^{2} / \mathrm{m}^{3}$, packing bed elements during their operation inside process units are often plugged. Other major fault of regular packing beds are their high cost and big specific gravity, as well as.

In many research works has been pointed out the critically high sensitivity of regular packing beds to the initial uniform distribution of liquid at the packing bed input $[9,12,16]$.

In the research work [19] are quoted results of experiences on using of sanitary absorbing packed columns with the diameter of $0,63 \mathrm{~m}$ and height of packing bed between $3,2 \mathrm{~m}$ and 5,2 m, respectively. The specified units allow, to perform the absorption purification of ammonia and chloride hydrogen waste (offluent) gases by using the solution of chloride ammonium. However, $8 \times 10 \mathrm{~mm}$ in-size Rashing rings [19] rings used in work don't provide the required reduction of energy consumption costs, because of big hydraulic resistance of a small and inefficient packing, the internal element surface of which isn't practically washed by interacting streams [16].

Using the elements of PFF packing type in contact apparatuses allows, to solve a problem of sanitary purification of waste gases in more compact space due to bigger development of specific surface, where hydraulic (fluid) resistance at the same time is lower.

While considering the presented analysis, urgent problem is a development of the new regular packing beds, which have got highly extended surface, but are manufactured from materials commercially obtainable according to the cost and are to certain extent free of the above mentioned faults.

In this report are presented concept notes of regular packing bed of new type made of cloth elements, as well as results of preliminary trials to research the hydrodynamics of cloth packing beds from various materials (silk, nylon, polyethylene, organza OSG-153).

\section{The concept of a regular packing made of cloth elements}

It has been suggested that the regular packing bed will be made in form of cloth "flag" system making free vibrational motions under the influence of incoming gas stream [18]. The tier of PFF type (fluctuating packing "flag") packing proposed for the column with $150 \mathrm{~mm}$ in diameter is presented in Figure 1.

The use of such packing involves the existing gas stream vortex-like flow in the volume of apparatus provided with the packing (please see Fig. 2). The specified vortex currents, for example, Karman's vortex street are intended to provide vibrational motions of cloth "flags" and so intensify heat-and-mass transfer processes in the contact apparatus.

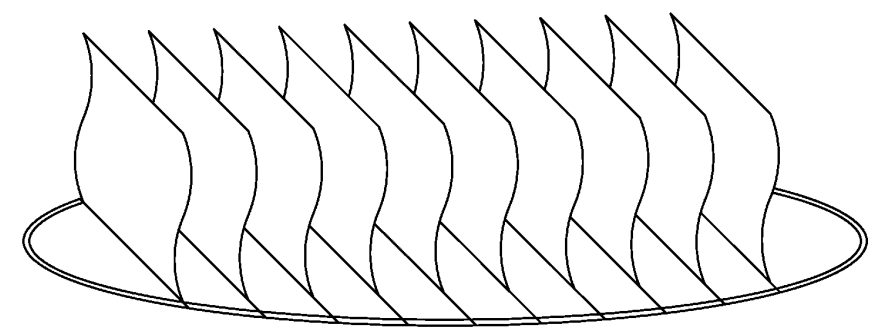

Fig. 1. General view of PFF packing bed tier 


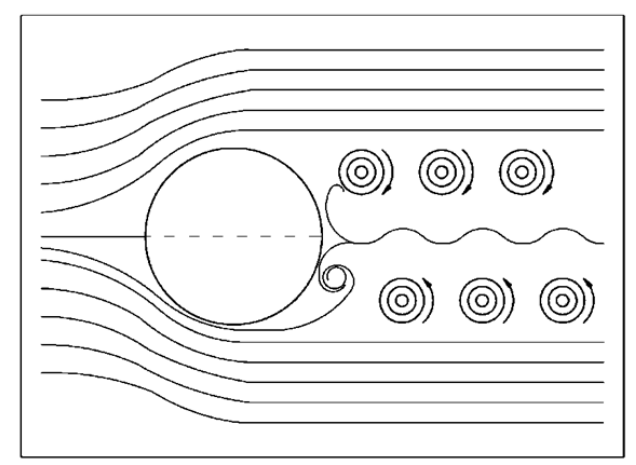

Fig. 2. Karman's vortex street scheme

Let's take a good look within outer problem of hydrodynamics at the diagram of flow around the elementary cylindrical body with the diameter $\mathbf{d}$ by stationary stream of gas with $\mathbf{W}_{\mathbf{0}}$ velocity. May the velocity of gas stream vary within the limits of Reynolds' numbers Re: $10^{0}<\operatorname{Re}<10^{7}$

Here:

$$
\operatorname{Re}=\left(\mathrm{W}_{0} * \mathrm{~d} 1\right) / v
$$

The characteristic curve of horizontal cylinder drag coefficient dependency $\zeta$ on Reynolds's number is shown in Fig. 3. The flow pattern corresponding to the segment AC on dependency diagram $\zeta=\mathbf{f}(\mathbf{R e})$ is of special interest for practical use, when implementing of heat-and-mass transfer processes (please see Fig. 3). As it seen from the diagram, with increase of Reynold's number the gas stream behind the stream-lined cylinder becomes asymmetric (please see Fig. 4). After the point $\mathbf{B}$ there is an area of the slowed-down stream, which starts making vibrational motions here and there. With further increase of Reynold's number on the segment BC, Karman's vortex street appears (please see Fig. 4).

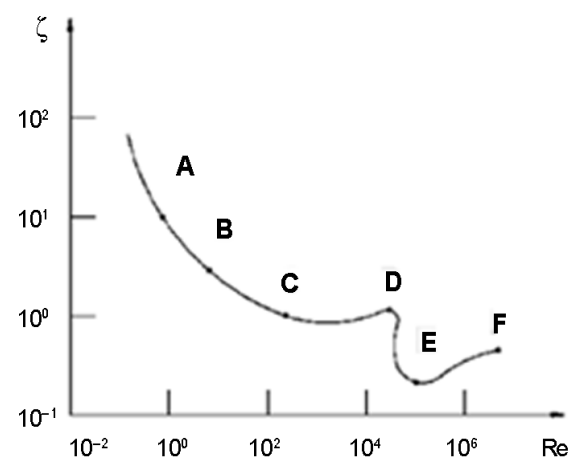

Fig. 3. Dependence of hydraulic resistance coefficient $\zeta$ from the specific value of Reynold's criterion in case of the stream-lined single cylinder
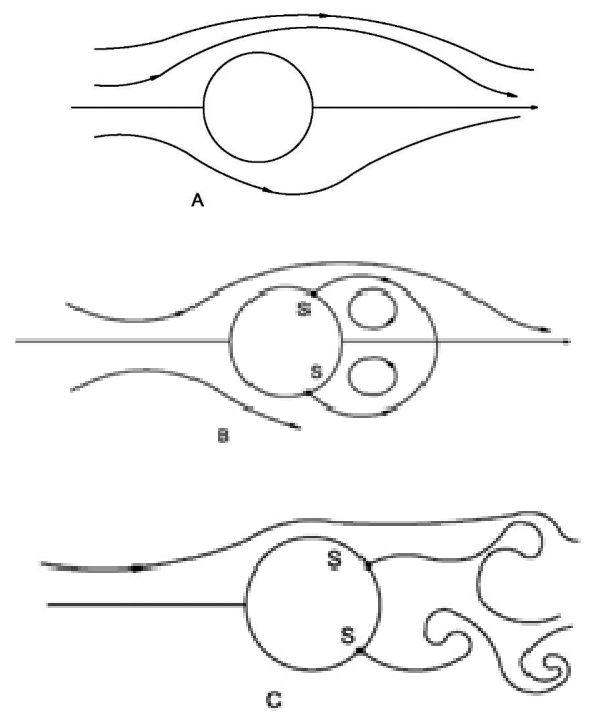

Fig. 4. Diagram of flow around the cylinder by cross stream of gas at various values of Reynold's criterion (notation of points $\mathbf{A}, \mathbf{B}$ and $\mathbf{C}$ please see in Fig. 3): $\mathbf{S}$ - breakaway points, in which there is a breakaway of boundary layer from the stream-lined body surface 
The value of hydraulic resistance coefficient can be assessed according to the following equation [19]:

$$
(\zeta / 2)=(\Delta \mathrm{P}) /\left(\rho^{*} \mathrm{~W}_{0}^{2}\right)=\mathrm{Eu} .
$$

\section{Hydrodynamic tests of PFF type packing bed}

Experiments were performed at the test stand which schematically shown in Figure 5. The column in diameter is $150 \mathrm{~mm}$.

Using of wire lattices as a generator of vortex currents is for PFF packing bed at packing one input of special interest. In this regard, previously were carried out hydrodynamic tests of the specified lattices with different free cross section $\mathbf{F}=\mathbf{d} 2 / \mathbf{D}$. Characteristics of the tested lattices are shown in Table 2.

Table 2. Characteristics of tested wire lattices

\begin{tabular}{|l|l|l|l|l|l|l|}
\hline № ח/п & 1 & 2 & 3 & 4 & 5 & 6 \\
\hline F, \% & 20 & 30 & 40 & 50 & 60 & 70 \\
\hline
\end{tabular}

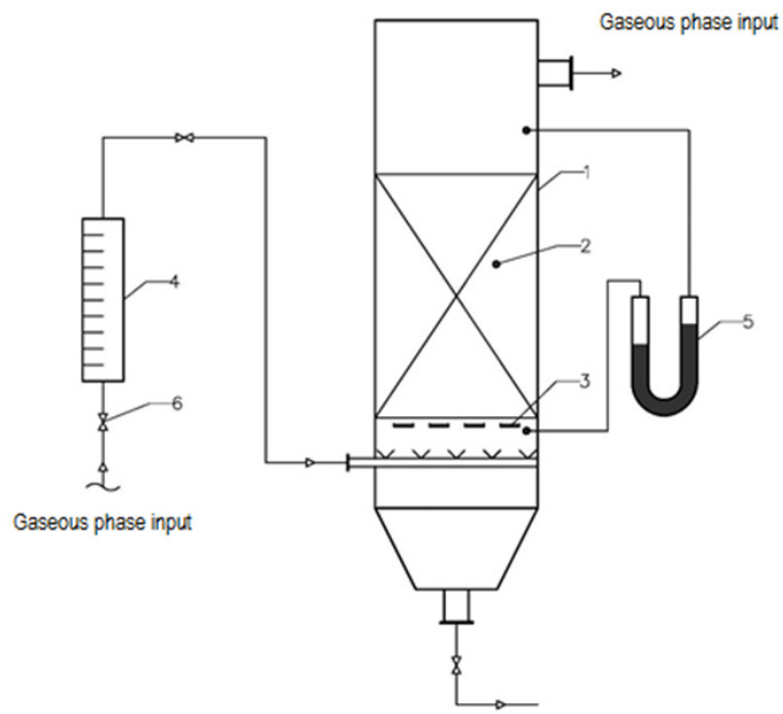

Fig. 5. Scheme of test facility: 1 - column housing; 2 - packing bed; 3 -gas-distributing lattices;

4 - variable area flowmeter (rotameter); 5 - differential pressure manometer; 6 - valve

The dependence of hydraulic resistance coefficients of tested lattices on the air stream velocity calculated per the full cross section of $\mathrm{W}_{0}$ in the range of $\mathrm{W}_{0}$ from $0,5 \mathrm{~m} / \mathrm{s}$ to $3,0 \mathrm{~m} / \mathrm{s}$ is presented in Figure 6 . The influence of free cross section of lattice $\mathrm{F}$ on the size of hydraulic resistance coefficient $\zeta$ at various velocities of air stream $\mathrm{W}_{0}$ is shown in Figure 7 . As it seen from presented diagrams, with increase of free cross section of wire lattices $\mathrm{F}$ from $20 \%$ to $70 \%$ the value of hydraulic resistance coefficients $\zeta$ at air stream velocity, for example, $\mathrm{W} 0=1,0 \mathrm{~m} / \mathrm{s}$ is will be reduce from 16,5 to 1,05 , i.e. by 15,7 times.

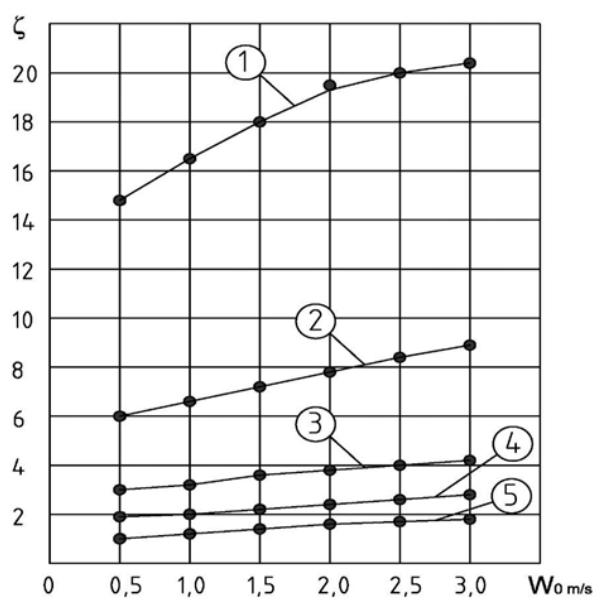

Fig. 6. Dependence of hydraulic resistance coefficient $\zeta$ of wire lattices with different free cross section $\mathrm{F}$ on the air stream velocity $\mathrm{W} 0: 1-\mathrm{F}=20 \%$ $2-\mathrm{F}=30 \% ; 3-\mathrm{F}=40 \% ; 4-\mathrm{F}=50 \% ; 5-\mathrm{F}=60 \%$

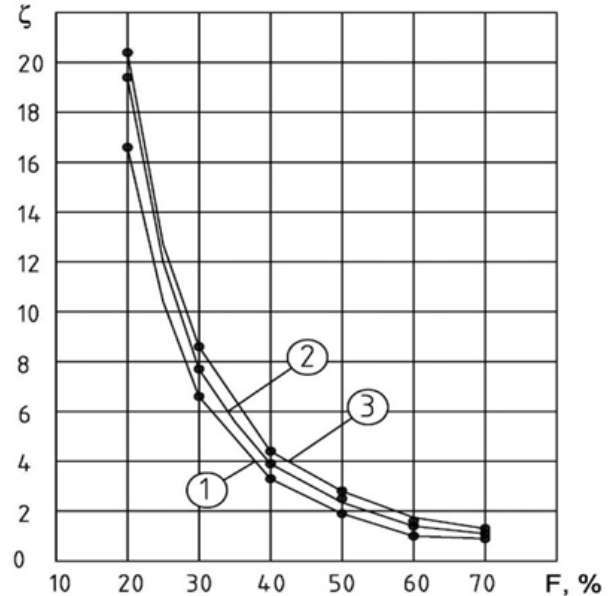

Fig. 7. Dependence of hydraulic resistance coefficient $\zeta$ of wire lattices on the size of their free cross section $\mathrm{F}$ at different velocities of air stream W0: $1-\mathrm{W}_{0}=1,0 \mathrm{M} / \mathrm{c} ; 2-\mathrm{W}_{0}=2,0 \mathrm{M} / \mathrm{c} ; 3-\mathrm{W}_{0}=3,0 \mathrm{M} / \mathrm{c}$ 
Hydrodynamic tests of PFF packing bed tier were carried out in the same column with a diameter of $150 \mathrm{~mm}$. The preciously tested lattice with the free cross section $\mathrm{F}=50 \%$ was used in the course of this set of experiments as a generator of gas stream vortex at the working volume input. The height of investigated cloth materials during those experiments varied between $50 \mathrm{~mm}, 100 \mathrm{~mm}$ and $140 \mathrm{~mm}$.

In the course of experiments while purging samples of packing beds in the column the gas stream velocity was W $0=1,0 \div 2,0 \mathrm{~m} / \mathrm{s}$. Visual observation (please see a photo in Fig. 8) showed that in specified range of velocities the tested types of packing bed elements made free vibrational motions with an amplitude $A=2 \pm 1 \mathrm{~mm}$. It was noted, that in doing so the greatest amplitude of packing bed cloth fluctuations created a polyethylene film from samples.
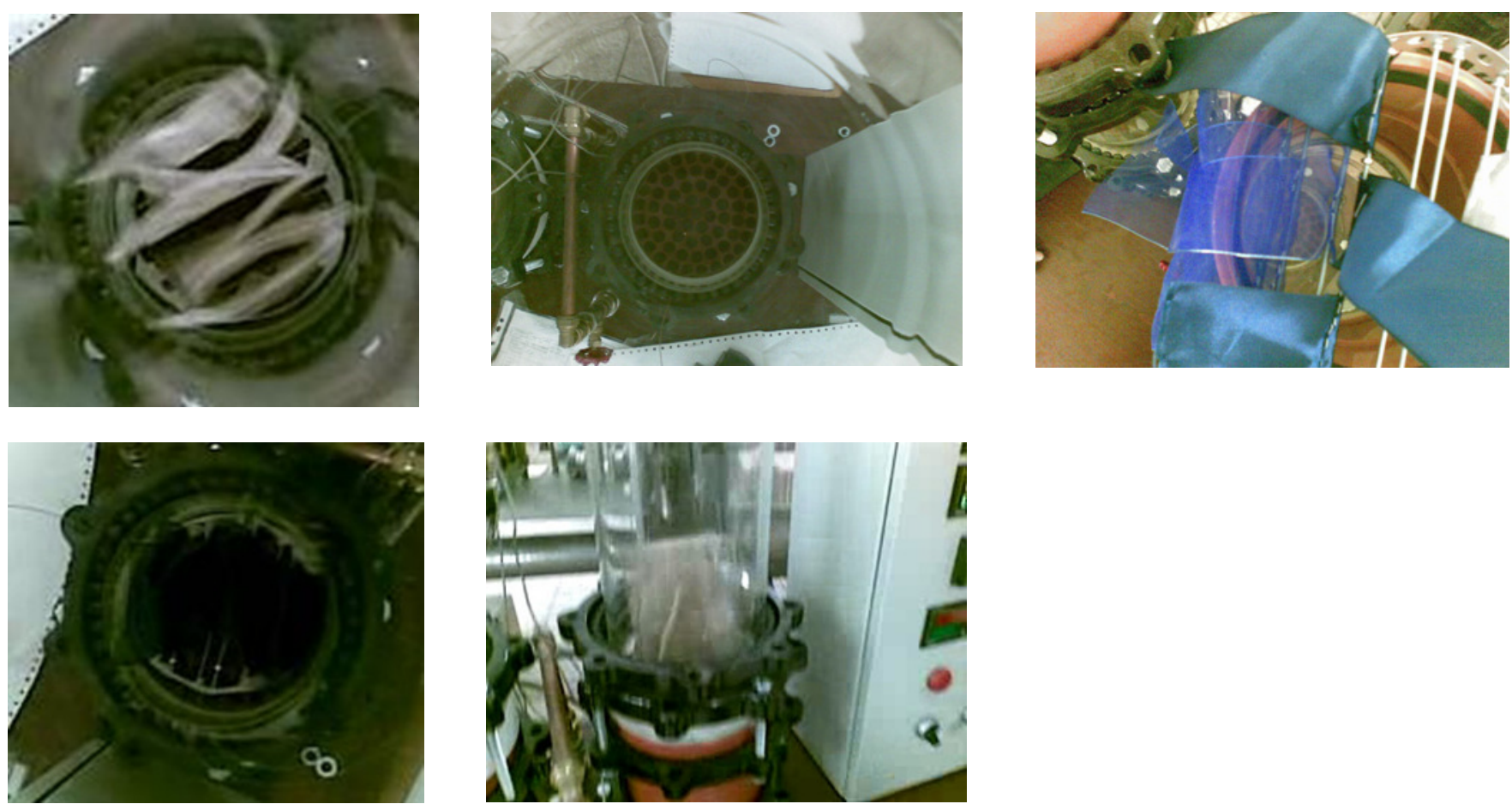

Fig. 8. Tests of PFF packing tier

\section{Conclusions}

1. It was conceptualized a regular PFF type packing bed made of cloth elements making free vibrational motions under the influence of ascending vortex-like gas flow.

2. Preliminary results of hydrodynamic tests of the suggested PFF packing bed tier made of different materials are presented. It is shown that the most promising from all tested materials is the polyethylene cloth.

\section{References}

[1] Богачева, Т. М.; Яруш, 3. Г. Перспективы повышения экологичности угольных ТЭС, Экология и промылиенность России, 2013, август, 5760 .

[2] Федеральная служба по гидрометеорологии и мониторингу окружающей среды. Институт глобального климата и экологии. Обзор фонового состояния окружающей природной среды на территории стран СНГ за 2009-2010 г.г. Под ред. Академика РАН Ю.А. Израэля. Downloads.igce.ru>publications/abz fon/of zon.pdf

[3] Пушнов, А.; Балтренас, П.; Каган, А.; Загорскис, А. Аэродинамика воздухоочистных устройств с зернистылм слоем. Вильнюс: Техника, $2010,348 \mathrm{c}$.

[4] PushnovA.; Petrashova, E. 2011. Air treatment apparatus of high capacity, in Environmental Engineering, The 8-th International Conference May 1920, 2011, Vilnius, Lithuania. Selected papers. Volume 1, Enviromental Protection, VGTU Press "Technika", 2011, 319-322.

[5] Polienova, E.; Valdberg, A. Complex cleaning of gases in the fibrous filters, in Environmental Engineering. The 8-th International Conference May 19-20, 2011, Vilnius, Lithuania. Selected papers. Volume 1, Envirunmental Protection, VGTU Press "Technika", $2011,275-278$.

[6] Витковская, Р. Ф. 2005. Разработка и исследование волокнистых катализаторов и контактных элементов для ресурсосбережения и охраны окружающей среды. Диссертация на соискание ученной степени доктора технических наук. СПб.: СПбГУТиД, 2005, 354 с.

[7] Billet, R. 1995. Packed towers in processing and environmental technology. Publisher Wiley - VCH; 1 edition (February 22, 1995$) 383$ p.

[8] Чиж, К. В.; Пушнов, А. С.; Вайнштейн, С. И.; Тимонин, А. С. 2008. Регулярные насадки для узла утилизации тепла скрубберного аппарата очистки отходящих газов, Сборник тезисов докладов конференции «Результаты фундаментальных исследований в области энергетики и их практическое значение». Москва, 24-26 марта 2008 г. М.: ОИВТ РАН, 2008, 166-167.

[9] Лаптев, А. Г.; Фарахов, М. И. 2008. Гидромеханические прочессы в нефтехимии и энергетике. Казань: Казанский государственный университет, 2008, 729 с. 
[10] Харитонов, А. А.; Пушнов, А. С.; Лагуткин, М. Г. 2011. Гидравлические испытания решетчатого контактного устройства скрубберного аппарата, Химическая промыиленность сегодня 6: 50-56

[11] Пушнов, А. С.; Соколов, А. С.; Бутрин, М. М. 2013. Методы интенсификации процесса тепло- и массообмена в колонных аппаратах с контактными устройтсвами, Известия МГТУ «МАМИ», 2013, №1(15), т.4: 237-242.

[12] Дмитриева, Г. Б. 2007. Гидродинамика и массообмен в структурированных насадках из гофрированных листов. Автореферат диссертации на соискание ученой степени кандидата технических наук. Иваново: Ив.ГХТУ, 2007, 19 с.

[13] Регулярная насадка для процессов абсорбции и ректификации. Каталог фирмы Sulzer Chemtech, 22.10.06. 40-11.05

[14] Регулярные насадки из гофрированного листового металла. Flexipac, Flexipac HC, Flexipac S, Intallox, Intallox STX. Каталог фирмы КОСНGLITSCH

[15] Mackowiak, J. 2010. Fluid Dynamics of Packed Columns. Principles of the Fluid Dynamics Design of Columns for Gas/Liquid and Liquid/Liquid Systems. Springer, 2010, 355 p. http://dx.doi.org/10.1007/b98397

[16] Каган, А. М.; Лаптев, А. Г.; Пушнов, А. С.; Фарахов, М. И. 2013. Контактные насадки промыиленных тепломассообменных аппаратов. Монография. Под ред. Лаптева А.Г. Казань: Отечество, 2013, 454 с.

[17] Никандров, М. И.; Никандров, И. С. 2012. Абсорбция аммиака и хлористого водорода раствором хлористого аммония , Хим. Технология 13(8): 492-495.

[18] Пушнов, А.; Севрюков, А.; Беренгартен, М. 2013. Колеблющаяся насадка типа «Флаг» из тканого материала. Šilumos energetika ir technologijos. Kaunas, 2013, 97-100.

[19] Пономаренко, В. С.; Арефьев, Ю. И. 1988. Градирни промылиленных и энергетических предприятий. Под общей ред. В.С. Пономаренко. М.:Энергоатомиздат, 1988, с. 155 . 